\title{
The Impact of Water-Related Pollution on Food Systems in Transition: The Case of Northern Vietnam
}

\author{
Vincent Linderhof ${ }^{1, *(\mathbb{D}}$, Marieke Meeske ${ }^{2} \mathbb{D}$, Vasco Diogo ${ }^{3} \mathbb{D}$ and Anne Sonneveld ${ }^{1}$ \\ 1 Wageningen Economic Research, Wageningen University and Research, P.O. Box 29703, \\ 2502 LS The Hague, The Netherlands; anne.sonneveld@wur.nl \\ 2 Oxfam Novib, 2514 HD The Hague, The Netherlands; marieke_meeske@hotmail.com \\ 3 Swiss Federal Institute for Forest, Snow and Landscape Research WSL, Zürcherstrasse 111, \\ CH-8903 Birmensdorf, Switzerland; vasco.diogo@wsl.ch \\ * Correspondence: vincent.linderhof@wur.nl; Tel.: +31-70-3358396
}

Citation: Linderhof, V.; Meeske, M.; Diogo, V.; Sonneveld, A. The Impact of Water-Related Pollution on Food Systems in Transition: The Case of Northern Vietnam. Sustainability 2021, 13, 1945. https://doi.org/10.3390/ su13041945

Academic Editor: Yusuf G. Adewuyi

Received: 31 December 2020

Accepted: 9 February 2021

Published: 11 February 2021

Publisher's Note: MDPI stays neutral with regard to jurisdictional claims in published maps and institutional affiliations.

Copyright: (C) 2021 by the authors. Licensee MDPI, Basel, Switzerland. This article is an open access article distributed under the terms and conditions of the Creative Commons Attribution (CC BY) license (https:// creativecommons.org/licenses/by/ $4.0 /)$.

\begin{abstract}
In Vietnam, agricultural practices such as fertilizer and pesticide use affect the landscape as well as the availability and safety of food. For instance, pesticides and fertilizer end up in surface water used for drinking water, crop irrigation, and in fish tanks. However, the link to actual food consumption and health is complex and information is lacking. This study considers potential water-related exposure to toxic hazards in northern Vietnam food systems, through the consumption of food commodities and of water. Water pollution is operationalized by considering the following two channels: (i) pesticide and nutrient leaching to surface water (share of surface water) and (ii) industrial runoff from facilities located in urban areas (share of urban areas). We explore how potential exposure to toxic hazard is related to food consumption choices. Using a sample of the Vietnam Household Living Standard Survey (VHLSS) for 2014, we estimate how shares of food consumption categories in total food consumption are affected by household and landscape characteristics, the latter also reflecting potential environmental pressures. In districts with higher shares of surface water, the share of fish consumption is higher and the share of meat consumption is lower. From an environmental and health perspective, households in water-rich areas thus may have a higher probability of being exposed to toxic chemicals due to higher fish consumption. In districts with higher shares of urban areas, the shares of meat and cereals in total food consumption value were lower, and the shares of fish and fruit and vegetables were higher. The results indicate that food consumption is affected by landscape characteristics that may also influence the level of exposure to water-related environmental pressures, and that this combined effect may potentially exacerbate food safety and health risks. The actual impact is more complex and should be analyzed with more sophisticated data and methods.
\end{abstract}

Keywords: Northern Vietnam; food system; food safety; food consumption; environmental pressures; water-related pollution

\section{Introduction}

Changing food patterns worldwide are resulting in increasingly complex and longer global food chains, which put pressure on food safety [1]. Food safety issues appear throughout the entire food chain, from production to consumption processes. The food systems approach recognizes the different perspectives in the food system from the agricultural production, value chain including distribution, traders, and retail to the consumer diets [2]. This approach allows us to analyze food security to the full extent of food availability, food accessibility, and food utilization including food safety. It thus allows to identify potential impacts of environmental pressures on food consumption and food security. Unsafe food practices are a danger for public health. Access to safe and nutritious food is key to sustaining and promoting good health. Food insecurity contributes to a poorer health status, and in turn a poorer health status makes people more job insecure, 
which might lead to lower incomes. Lower incomes again may lead to increased risk of food insecurity, for example, by incentivizing purchases of cheaper but less healthy or less safe foods which may be richer in energy (high in fat and sugar) to satisfy hunger. These dynamics, combined with trade-offs between medication, healthcare, and food purchasing, may result in chronic diseases and worsening of mental health $[3,4]$.

In Vietnam, there are still a lot of concerns with respect to the safety of food systems [5], and the relationship between poor practices concerning food production, processing, and consumption and food safety is receiving widespread media attention [6]. Around 5 to $6 \%$ of its gross domestic product (GDP) is spent on healthcare, with a large share of these costs being related to foodborne diseases such as acute diarrhea and poisoning that result from contaminated food [5]. Despite growing awareness of foodborne diseases, the information on risks to health issues and socioeconomic development caused by unsafe food practices remain often incomplete. Many initiatives have been undertaken, but mainly for the purpose of exporting food products that are considered "safe" [5]. Accurate data on the complete picture of costs, implications, and outbreak numbers of foodborne disease is often lacking. Hence, policy makers face difficulties tackling the problem and allocating resources [5,7].

There are multiple channels in which the food system may be affected by environmental pressures. On the one hand, the use of chemical fertilizers and pesticides in agriculture allows to achieve higher levels of crop productivity thus improving food availability, but on the other their overuse may also have an impact on the safety of the food products. Moreover, the runoff of excessive residues of chemical fertilizers and pesticides contaminates the soil, groundwater, and surface water bodies. This implies that freshwater water sources that are used for drinking water purposes may be affected by food production as well. As a result of political and economic reforms, the use of agrichemicals such as pesticides and fertilizers has dramatically increased in Vietnam over the last decades. Pesticide use, for example, has increased from 15,000 tons in 1991 to about 105,000 tons in 2012 [8,9]. Not only the quantity but also the number of active ingredients and pesticide formulations has increased considerably [10]. The rapid increase in pesticide use is attributed to a combination of biophysical factors (increasing production area of vegetable and fruit crops, and increasing resistance of pests and diseases) and incorrect pesticide use by farmers [11]. Furthermore, surveys conducted across the country have demonstrated that farmers tend to be negligent in their use and disposal of pesticides [12,13]. Pesticide use per hectare is relatively high in the production of vegetables compared to other food consumption categories [8]. While application doses are relatively low when compared to Asian developed countries (e.g., Japan and South Korea), they are substantially higher than other developing countries in the region (e.g., Philippines and Bangladesh) [14,15]. In addition, the use of fertilizers by farmers in Vietnam is generally suboptimal, with farmers often applying nitrogen fertilizer in doses higher than recommended and neglecting phosphorus and potassium levels $[16,17]$. Regulations on the use of fertilizer and pesticides and training on safe farming practices provided by representatives of the government failed in the establishment of safe production processes and distribution systems. The reason for this is twofold: (i) the failure of the authorities to support market actors, and (ii) the absence of trust in safe production as a better alternative to conventional practices. Meanwhile, stakeholder empowerment and encouragement may be more effective to change the stakeholder's behavior towards safer food practices [6,18].

In addition, industrialization has also increased over the years, with industrial production in Vietnam growing more than 10\% annually during the period of 1990-2005 [19]. Despite the contribution to livelihoods, rapid industrialization has also brought about considerable environmental pressures and health impacts due to the resulting widespread pollution $[20,21]$. The spatial pattern of industrial pollution roughly mirrors the current structure of industrial output. The Southeast (nearly half of total toxic pollution and one third of total water pollution) and Red River Delta (one quarter of total air pollution and one fifth of total water pollution) are the most polluted regions [21]. The main polluting 
industries are the manufacturers of chemicals (e.g., fertilizers, pesticides, and pharmaceuticals). The metal processing plants are of primary concern, due to the emission of several high-priority hazardous chemicals and metal pollutants into the air, water, and land [19]. Industries producing footwear, fertilizer, and nitrogen compounds are among those with the highest pollution loads. Industries producing fertilizer, pesticide, paper and paperboard, plastics, and leather sectors are responsible for water pollution [5]. In terms of the food processing subsector, seafood processing stands out due to the large scale of production and high pollution load levels. Contamination of drinking water through industrial waste results from various types of industrial processes and disposal practices. The occurrence of industrial wastewater contamination is widespread across Vietnam, since most industrial areas do not have wastewater treatment systems installed [20], particularly due to financial constraints of small- and medium-sized enterprises preventing investment [22]. Other contamination pathways include seepage of chemicals through the soil into groundwater from waste disposal sites, runoff of chemicals that are washed into water bodies from the soil where they were used or spilled, and aerial dispersion of substances into rainwater and dust particles. Emission of pollutants often include highly toxic organic wastes such as pesticide residues, solvents, cleaning fluids, dissolved residue from fruit and vegetables, and lignin from pulp and paper, and also inorganic waste effluents, namely brine salts and toxic metals such as zinc, copper, cadmium, chromium, lead, and mercury [19].

Polluted water increases the risk of various diseases, such as typhoid, cholera, and eye infections [23]. There is a variety of water sources, and in some of the water sources, unsafe levels of chemicals are found. Different water sources are categorized in improved and unimproved water sources. Improved water sources include piped water (dwelling, year/plot, public tab/standpipe), tube-well, protected well, protected spring, harvested rainwater, and bottled water. Unimproved water sources include unprotected well, unprotected spring, and surface water [23-25]. The results of the Multiple Indicator Cluster Survey of 2014 showed that $92 \%$ of the total population in Vietnam had access to improved water sources. Of the population living in urban areas, $98.2 \%$ had access to improved water sources, and in rural areas $89.1 \%$ of the population had access to improved water sources [25]. Access to improved water sources does not necessarily mean that people have access to safe drinking water. In the Mekong delta, samples of groundwater, harvested rainwater, flocculated canal water, and bottled water contained pesticide residues. Hence, even though bottled water and rainwater are defined as improved water sources in different studies, the water could still be polluted. Pesticide residues concentrations are still found in harvested rainwater, since rainwater is often stored in the same tanks where water from other water sources (e.g., canal water) is stored during the dry season. Canal water might contain pesticide residues and therefore transfer pesticides from canal water to harvested rainwater the next rainy season [24].

The different ways of impact of environmental pressures on the food system are hard to measure and difficult to disentangle. In most research, the food safety issue is considered from an individual consumer perspective emphasizing residues in food or unsafe drinking water [5]. The impact of environmental pressures on diets in Vietnam has not been analyzed with the food system approach. In this study, we focus attention on the water-related environmental pressures on food consumption in Vietnam, and particularly we explore how potential exposure to water pollution is related to food consumption choices. This is operationalized by considering the overall consumption pattern in relation to the potential existence of environmental pressures, the latter usually not being considered in previous analyses. This approach is applied to a case study in northern Vietnam, for which detailed data on both household and landscape characteristics are available. 


\section{Materials and Methods}

\subsection{Approach}

One way to analyze food consumption is to apply demand system approaches. Within the context of low and middle income countries (LMIC), the food demand systems modeling approach has occasionally been applied when analyzing food demand such as in India [26], Nigeria [27], and South Africa [28]. In Vietnam, there are several studies that analyzed food demand systems. An example is the linear approach of the Almost Ideal Demand System [29]. He used the VLSS of 2004 and distinguished three categories of food, namely rice, meat/fish, and non-rice food. The first two are characterized as normal goods, which means that the income elasticities are positive and lower than one. Non-rice food has an income elasticity that is larger than one, and thus it is characterized as a luxury good. Another study applied a similar approach where several food commodities were included with the VHLSS data for 2006 [30].

However, food demand systems are based on the consumer theory which assumes that consumers or households behave rationally [31]. In addition, there is often an implicit assumption that income and income generating activities are separated from consumer decisions. From a theoretical point of view, this assumption, however, is not likely to be valid for households practicing agricultural activities, because consumer and producer decisions are non-separable as explained by the theory of farm households [32]. The main concern with evaluating a full food demand system in LMIC is that key assumptions might be violated due to the presence of food consumption from own agricultural production and from gifts by relatives and friends. Therefore, we do not use a full demand system approach rather than a system of food consumption equations.

The main interest of this study is the impact of landscape characteristics on food consumption for both farm/non-farm households, and households which do and do not consume food away from home (FAFH). It includes prepared meals purchased in restaurants, hotels, or from street vendors. FAFH consumption is significant in Vietnam [33].

\subsection{Methodology}

The model is written as follows:

$$
Y_{i j}=\beta_{0}+\beta_{i} X_{i}+\beta_{2 j} S_{d(i)}+u_{i j}
$$

where $Y_{i j}$ represents the food consumption of household $i$ of food consumption group $j$, with households $i=1, \ldots, N$ and food consumption group $j=1, \ldots, K$. On the left-hand side of Equation (1), $X_{i}$ represent the vector of household characteristics, $S_{d(i)}$ represents a set of landscape indicators, and $u_{i j}$ is the error term. The landscape indicators $S_{d(i)}$ are not measured at the individual household level but at the level of districts with the index $d=1$, $\ldots, D$. Each household $i$ is associated with a district $d(i)$. In the sample, a district is linked to multiple households.

Landscape characteristics may influence different aspects of consumer behavior. These aspects are often absent in high resolution surveys (household surveys or surveys of individuals), although the location of the household or individual is known. Furthermore, landscape characteristics might also form some sort of contextual reference of individual indicators. As fertilizer use of farmers is often observed in questionnaires on agricultural production, the fertilizer use at the community level or district level tells how common (or not) the use of fertilizer is in the area. In this way, the fertilizer use of one farmer is referenced to the common level in the area. Moreover, the addition of landscape effects might also reveal spillover effects which are not encountered easily. Obviously, the inclusion of regional specific dummies could also encounter the regional effects, but when regional characteristics differ significantly across communities, districts, or regions, these indicators allow to add explanatory power to the regression estimations. 
For this study, land cover configuration, population density, and accessibility to main urban centers were included as indicators of landscape characteristics. These indicators were used as explanatory variables for the analyses of the food demand system equations in Equation (1) for rural and urban settings of the study area. They are computed at the district level in order to capture the potential effects of local determinants of food consumption and demand, and of spatial externalities in the use of pesticides and fertilizers at the regional level, respectively. The set of landscape indicators is subsequently integrated with the set of household indicators according to the district/province where the household residence is located, i.e., each household in district/province $X$ has the same value for landscape indicator $Y$.

With respect to the land cover configuration, the effect of the prevalence of urban areas and water bodies within an administrative unit was investigated. These land-use types were selected since they influence not only the variety and availability of food items [33-38], but also the exposure to health risks [24,39-41]. The contribution of urban areas and water bodies to the overall land cover configuration was calculated for each administrative unit in terms of share of the total area of the territory that is devoted to each of these land cover types (in \%), as follows:

$$
L C_{s r}=A_{i r} / A_{r}=n_{i r} / n_{r}
$$

where:

$L C_{s r}$ is the share of land cover $i$ in the district $r$ (in \%);

$A_{i r}$ is the area devoted to land cover $i$ in district $r$;

$A_{r}$ is the total territorial area of district $r$;

$n_{i r}$ is the total number of grid cells with land cover i located within district $r$; and

$n_{r}$ is the total number of grid cells located within district $\mathrm{r}$.

Average population density was calculated by dividing the amount of people living within an administrative unit with the total area of that territory (in people $/ \mathrm{km}^{2}$ ), as follows:

$$
\text { PopD } D_{r}=\text { Pop } r / A_{r}=\Sigma_{c} \text { Pop }_{c, r} / \Sigma_{c} A_{c, r} \text {, for } c=1, \ldots, n_{r}
$$

where

$\operatorname{PopD}_{r}$ is the average population density of district $r$ (in people $/ \mathrm{km}^{2}$ );

$\mathrm{Pop}_{r}$ is the population in the district $r$;

$A_{r}$ is the total area of the district $r$;

Pop $p_{\mathrm{c}, \mathrm{r}}$ is the population in grid cell $c$, located within district $r$;

$A_{c, r}$ is the area of grid cell $c$; and

$n_{r}$ is the total number of grid cells located within district $r$.

To investigate the extent to which the population of an administrative unit is well connected to the main urban centers, the average population-weighted accessibility is calculated as follows:

$$
P W A_{r}=\left(\Sigma_{c} \text { Pop }_{c, r} \text { Access }_{c, r}\right) / \Sigma_{c} n_{c, r} I\left(\text { Pop }_{c, r}\right) \text { for } c=1, \ldots, n_{r}
$$

where:

$P W A_{r}$ is the average population-weighted accessibility level in district $r$ (in person*minutes); $P o p_{\mathrm{c}, \mathrm{r}}$ is the population in grid cell $c$, located within district $r$; Access $_{c, r}$ is the accessibility level observed in a grid cell $c$; and $I($.$) is the binary function which equals 1$ if the value of $P o p_{c r}$ is positive, and 0 otherwise.

Thus, the denominator is Equation (4) indicates the total number of grid cells located within district $r$ in which population is observed. 
Additional landscape indicators were considered as explanatory variables, such as share of irrigated land and average elevation. However, a quick analysis of correlation coefficients of the available landscape characteristics showed high and significant values. The selection of the landscape characteristics to be included in the model was based upon the lowest correlation values possible.

From the landscape indicators and the associated water-related environmental pressures, three exposure profiles were defined as presented in Table 1.

Table 1. Exposure to environmental pollution and health.

\begin{tabular}{cccc}
\hline & Exposure Profile & Share of Surface Water & Urban Share \\
\hline & & Danger of Waterborne Diseases & $\begin{array}{c}\text { Danger of Health Issues Related } \\
\text { to Emission on Toxic Substances }\end{array}$ \\
\hline I & High & High & High \\
\hline IIa & Moderate & High & Low \\
\hline b & Moderate & Low & High \\
\hline III & Low & Low & Low \\
\hline
\end{tabular}

The consumer is highly exposed if the shares of both surface water and urban areas is high. The exposure is low if both shares are low. In the case that either one of the shares is high and the other low, the exposure was defined as moderate. From our analysis, we cannot identify whether or not there is a difference in impact of the environmental pollution from surface water or urban areas.

\section{Data}

\subsection{Vietnam Household Living Standards Survey (VHLSS)}

This study uses one cross-section of the Vietnam Household Living Standards Survey (VHLSS) for 2014. The VHLSS was conducted by Vietnam's General Statistics Office (GSO) in collaboration with the World Bank. The survey is representative at the national and regional level. The survey includes 9399 households in Vietnam, from which $70.4 \%$ live in rural and $29.6 \%$ in urban areas.

VHLSS2014 has information on food consumption and expenditures and demographic and socio-economic characteristics of the households. Based on the food consumption data for the households, we constructed the shares of food consumption categories in the total consumption value and in the total caloric intake. We calculated the total caloric intake of the household by taking the value of total consumption of the each of the 54 food items, dividing it by the price of caloric intake per food item (Table A1 in the Appendix A), and summing the caloric intake of consumption per food item. Then, the shares of food consumption categories in total food consumption value were calculated. The food consumption categories were cereals, meat, fish, fruit and vegetables, dairy, FAFH, other food products. The available data on health expenditure in the VHLSS, the data source of this paper, are limited. Data on the different reasons to visit medical services, the household expenditures on both residential and non-residential treatment, and expenses on medicine and medical facilities are available. There is no data available for the health care costs linked to foodborne diseases or other diseases or symptoms related to unsafe food practices (e.g., polluted water). 
As defined in the previous section, sources of drinking water influence also the health status of people. The VHLSS contains information on the different sources of drinking water and also information if the drinking water is treated (boiled, filtered, chemicals used) before consumed. Different drinking water sources defined in the VHLSS are tap water reaching the house, public tab water, drilled well, protected dug well, unprotected dug well, protected stream well, unprotected stream well, bought water, rainwater, and other. Tap water reaching the house, public tab water, drilled well, protected dug well, protected stream well, bought water, and rainwater were categorized as improved water sources. Unprotected dug well and unprotected stream well are categorized as unimproved water sources.

The survey of the northern regions was checked for outliers in the sections of food consumption, agricultural production, and household characteristics. In total, 340 households were excluded from the sample because there were missing variables or extreme values. For the caloric intake per Adult Male Equivalent (AME) per household, for instance, we used a range of 500 to 5000 kilocalories, and households with values outside this range were excluded. This leaves us with a sample of 5381 households.

Based on earlier studies, we selected a number of household characteristics that are likely to contribute to the explanation of food consumption in Vietnam. The household characteristics include the following indicators:

- a dummy which equals to 1 if the households lives in an urban area and 0 otherwise;

- a dummy which equals to 1 if the urban household is involved in agriculture and 0 otherwise;

- the household size;

- the dependency ratio = share of children and elderly in the household;

- a dummy for ethnic minorities in the northern mountain region;

- $\quad$ age of the household head;

- gender, i.e., a dummy which equals to 1 if the household head is male and 0 otherwise;

- education with dummies for the categories (1) no education, (2) primary education, (3) lower secondary education, (4) higher education, and (5) college or higher education;

- income with dummies for the income quartiles; and

- $\quad$ source of drinking water with three dummies namely, tap water, water well, and water stream.

For the household income, the quartiles of income were identified. The quartiles were assigned for the complete survey, and we only use a sample. As a result, the shares of the income quartiles might deviate from the expected $25 \%$. Furthermore, income class 1 represents the group of households with the lowest income, and income class 4 represents the households with the highest income.

\subsection{Spatial Data}

In order to compute the landscape indicators described in Section 2.2, several spatial datasets were collected, as summarized below in Table 2. All datasets were re-projected to WGS84 projection and clipped with Vietnam country borders. Since there was no need to combine datasets with different spatial resolutions for the computation of the indicators, we refrained from resampling the grid cell size of the raster datasets, in order to avoid introducing additional mapping errors.

The landscape characteristics were derived from the spatial information retrieved from the Japan Aerospace Exploration Agency (JAXA). The High-Resolution Land Use and Land Cover Map of the Northern Region of Vietnam includes the share of surface water and the share of urban area measured at district level. Maps are only available for northern Vietnam, and we use this sample of the VHLSS 2014. 
Table 2. Spatial data sources used to compute landscape indicators.

\begin{tabular}{|c|c|c|c|c|c|}
\hline Dataset & Spatial Extent & $\begin{array}{c}\text { Spatial } \\
\text { Resolution }\end{array}$ & $\begin{array}{l}\text { Temporal } \\
\text { Coverage }\end{array}$ & Source & Indicators Computed \\
\hline $\begin{array}{l}\text { High-Resolution Land Use } \\
\text { and Land Cover Map }\end{array}$ & $\begin{array}{c}\text { Northern Region } \\
\text { of Vietnam }\end{array}$ & $250 \mathrm{~m}$ & 2015 & EORC, JAXA & Land cover share \\
\hline $\begin{array}{l}\text { Global Human Settlement } \\
\text { (GHS) population grid }\end{array}$ & Global & $1 \mathrm{~km}$ & 2015 & EC-JRC & $\begin{array}{l}\text { Population density and } \\
\text { population-weighted } \\
\text { accessibility to cities }\end{array}$ \\
\hline $\begin{array}{l}\text { Malaria Atlas Project (MAP) } \\
\text { accessibility to cities }\end{array}$ & Global & $1 \mathrm{~km}$ & 2015 & $\begin{array}{l}\text { Malaria Atlas } \\
\text { Project }\end{array}$ & $\begin{array}{l}\text { Population-weighted } \\
\text { accessibility to cities }\end{array}$ \\
\hline
\end{tabular}

Figure 1 shows that the share of both surface water and urban area is highest in the city of Hanoi and surrounding area. In addition, the area along the coast at the south of Hanoi shows a relatively high share of surface water area.

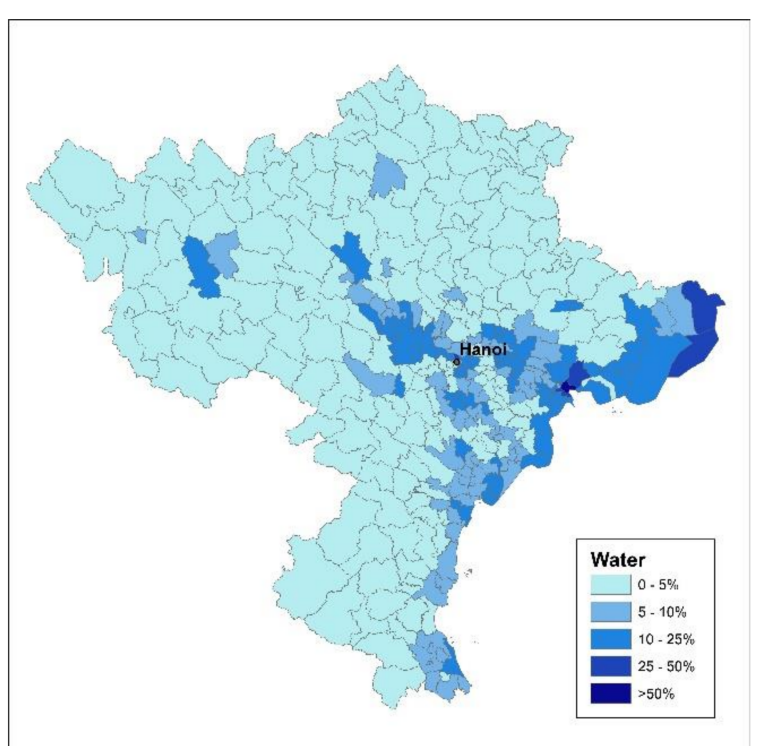

(A)

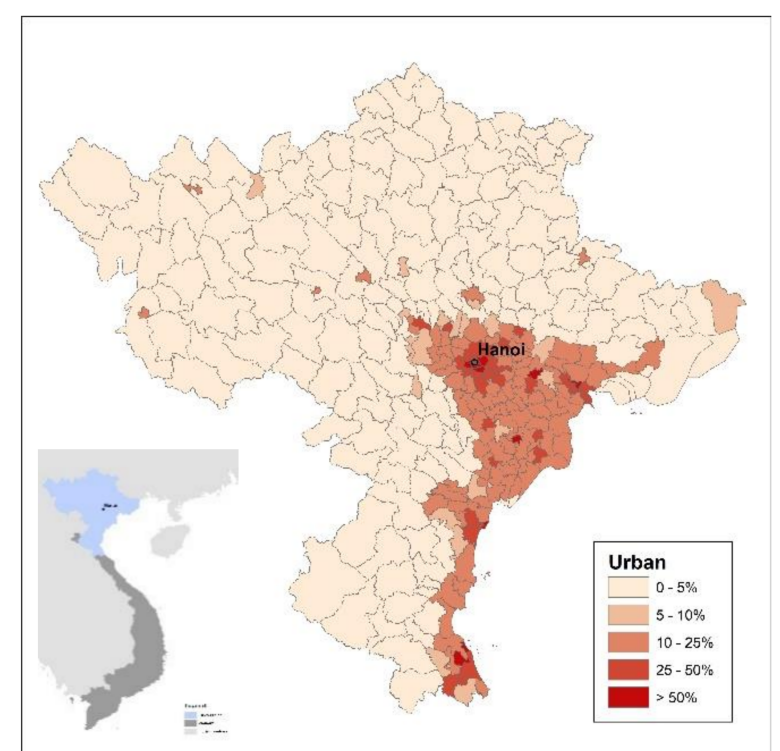

(B)

Figure 1. Share of water (panel (A)) and share of urban areas (panel (B)) in districts in northern Vietnam.

\subsection{Combined Data}

For our analysis, we used the VHLSS for 2014 because this survey is closest to the period of data collection of the spatial data, see below. Moreover, we selected the three northern provinces (Red River Delta, Midlands and Northern Mountains, and Northern and Coastal Central Region) due to the fact that spatial information was only available for these three provinces. The survey of the three northern regions consists of 5381 households (i.e., cleaned data). We merged the available spatial data to the household survey. For 1622 households, there is no information on the district characteristics in the spatial data base, so that the resulting sample consists of 3759 households.

\subsection{Descriptive Statistics}

\subsubsection{Food Consumption Indicators}

Table 3 presents the averages of the food consumption categories in the total consumption value and the caloric intake. 
Table 3. Descriptive statistics of the households' food consumption value and caloric intake per month for the food consumption categories.

\begin{tabular}{ccccccccc}
\hline & \multicolumn{3}{c}{$\begin{array}{c}\text { Food Consumption Value } \\
(\mathbf{1 0 0 0} \text { Vietnamese Dong) }\end{array}$} & \multicolumn{4}{c}{$\begin{array}{c}\text { Caloric Intake } \\
\text { (kcal) }\end{array}$} \\
\hline Variable & Mean & SD & Min & Max & Mean & SD & Min & Max \\
\hline Cereals & 994.3 & 498.2 & 0 & 5722 & 142,191 & 72,833 & 0 & 528,065 \\
Fruit and Vegetables & 311.4 & 249.8 & 0 & 2740 & 14,450 & 9179 & 0 & 96,644 \\
Meat & 753.0 & 559.8 & 0 & 5897 & 19,911 & 13,243 & 0 & 139,820 \\
Fish & 377.5 & 414.7 & 0 & 4600 & 3400 & 3050 & 0 & 35,094 \\
Dairy products and eggs & 290.8 & 563.4 & 0 & 7401 & 3606 & 4569 & 0 & 50,307 \\
Food away from home & 1065.2 & 1875.7 & 0 & 36,540 & 41,514 & 60,204 & 0 & 440,093 \\
(FAFH) & 417.5 & 301.1 & 0 & 7784 & 24,576 & 15,673 & 0 & 359,769 \\
Other & & & & & & &
\end{tabular}

The share of the consumption value is the highest for cereals, namely a share of $29.6 \%$, followed by meat with FAFH with a share of $19.1 \%$ and $17.0 \%$ respectively, see Figure 2 . The category dairy products and eggs has the smallest share with only 0.0563 followed by fruit and vegetables with $8.1 \%$.

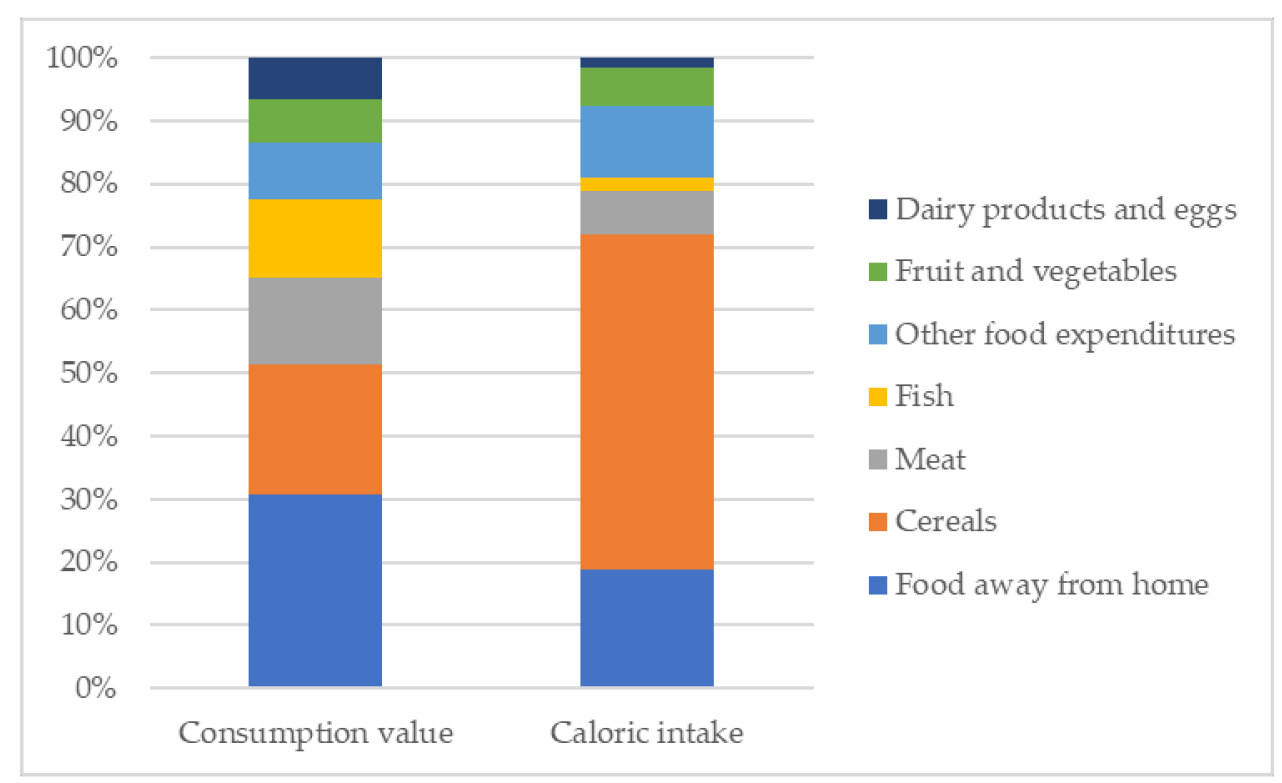

Figure 2. Share of food consumption categories in the total food consumption value and the caloric intake.

For the share of calorie intake, cereals represent more than half of the total share, namely 0.5791 . FAFH followed cereals as the second highest share of calorie intake with a share of 0.1371 . Dairy products and eggs as well as fish both counted the smallest shares in calorie intake with a share of 0.0149 .

\subsubsection{Landscape Characteristics}

The average share of urban areas equals $15.5 \%$ and the average share of water equals 6.3 , see Table 4 . The accessibility to the nearest city (population times minutes divided by 1000) equals 0.0583 and the average population density equals 1.7807. 
Table 4. Descriptive statistics of the landscape characteristics.

\begin{tabular}{ccc}
\hline Variable & Mean & SD \\
\hline Ratio of urban area in the district & 0.1551 & 0.2003 \\
Ratio of surface water area in the district & 0.0626 & 0.0677 \\
Accessibility of the district & 0.0583 & 0.1762 \\
Population density of the district & 1.7807 & 5.0168 \\
\hline
\end{tabular}

\subsubsection{Household Characteristics}

Table 5 shows that a quarter of the households in the sample lives in urban areas. Approximately $25-30 \%$ of the urban people were involved in agriculture practices, which equals to $7.1 \%$ of the households in the sample. The average dependency ratio (i.e., ratio of household members below an age of 16 and above an age of 64) equals 0.3261 , and the average household size equals 3.8 household members. In the northern mountain region, $20.6 \%$ of the households belong to an ethnic minority. The average age of the head of the households equals 50 years old and $78.6 \%$ of the sample is represented by men. Of the household heads, $11.6 \%$ did not complete a formal education, $21.6 \%$ completed primary education, $40.4 \%$ completed lower secondary education, $19.4 \%$ higher secondary education, and $7.0 \%$ completed college or a higher degree.

Table 5. Descriptive statistics of the household characteristics.

\begin{tabular}{|c|c|c|c|c|}
\hline Variable & Mean & SD & Minimum & Maximum \\
\hline Urban ( 1 if household head (hh) lives in urban area, $0=$ otherwise) & 0.2525 & 0.4345 & 0 & 1 \\
\hline $\mathrm{HH}$ is farmer ( 1 if hh in urban areas is farmer, 0 otherwise) & 0.0708 & 0.2565 & 0 & 1 \\
\hline Dependency ratio & 0.3261 & 0.2729 & 0 & 1 \\
\hline Household size & 3.83 & 1.52 & 1 & 11 \\
\hline $\begin{array}{l}\text { Ethnicity ( } 1 \text { if hh lives in northern mountain region and hh belongs } \\
\text { to minority, } 0=\text { otherwise) }\end{array}$ & 0.2056 & 0.4042 & 0 & 1 \\
\hline Age head & 50.3 & 13.8 & 16 & 105 \\
\hline Gender head $(1=$ male, $0=$ female $)$ & 0.7864 & 0.4099 & 0 & 1 \\
\hline No education & 0.1163 & 0.3206 & 0 & 1 \\
\hline Primary education & 0.2157 & 0.4114 & 0 & 1 \\
\hline Lower secondary education & 0.4044 & 0.4908 & 0 & 1 \\
\hline Higher secondary education & 0.1937 & 0.3952 & 0 & 1 \\
\hline College or higher & 0.0700 & 0.2551 & 0 & 1 \\
\hline Income quartile 1 & 0.2700 & 0.4440 & 0 & 1 \\
\hline Income quartile 2 & 0.2381 & 0.4260 & 0 & 1 \\
\hline Income quartile 3 & 0.2509 & 0.4336 & 0 & 1 \\
\hline Income quartile 4 & 0.2410 & 0.4278 & 0 & 1 \\
\hline Source drinking water tap water (rural) & 0.2626 & 0.4401 & 0 & 1 \\
\hline Source drinking water well (urban) & 0.4009 & 0.4901 & 0 & 1 \\
\hline Source drinking water well (rural) & 0.4254 & 0.4945 & 0 & 1 \\
\hline Source drinking water stream (urban) & 0.0915 & 0.2884 & 0 & 1 \\
\hline Source drinking water stream (rural) & 0.1418 & 0.3489 & 0 & 1 \\
\hline
\end{tabular}

In rural areas, $26.3 \%$ of the households use tap water as main source of drinking water, $42.5 \%$ of the rural households use a well as main source of drinking water, and $14.2 \%$ of the households use a stream as main source of drinking water. In urban areas, $40.1 \%$ of the households use a well as main source of drinking water, and $9.2 \%$ of the household use a stream as main source of drinking water.

\section{Results}

Following the specification in Equation (1), we regressed the share of food consumption categories on a series of household characteristics and spatial district landscape characteristics using the sample presented in the previous section. To avoid overidentification, six of the seven food consumption categories in our analyses were included, namely 
cereals, fruit and vegetables, meat, fish, dairy products and eggs, and food away from home. The category "other food and beverages" was excluded to avoid overidentification of the system of equations. First, Ordinary Least Squares (OLS) regressions to estimate the coefficients of the six specifications were explored and the residuals turned out to be highly correlated. Therefore, we applied the seemingly unrelated regressions equations (SURE) approach to calculate robust standard errors for the coefficient. Table 6 shows the results of the SURE model, and we will focus attention on the discussion of the significant effects of the results.

Table 6. Regression results of the seemingly unrelated regression equations (SURE) \#.

\begin{tabular}{|c|c|c|c|c|c|c|}
\hline Variables & Cereals & $\begin{array}{c}\text { Fruit and } \\
\text { Vegetables }\end{array}$ & Meat & Fish & $\begin{array}{c}\text { Dairy } \\
\text { Products } \\
\text { and Eggs }\end{array}$ & FAFH \\
\hline \multicolumn{7}{|l|}{ District characteristics } \\
\hline Urban & $\begin{array}{c}-0.1218^{* * *} \\
(0.0243)\end{array}$ & $\begin{array}{l}0.0212^{* *} \\
(0.0086)\end{array}$ & $\begin{array}{c}-0.0667^{* * * *} \\
(0.0178)\end{array}$ & $\begin{array}{c}0.0258^{* *} \\
(0.0131)\end{array}$ & $\begin{array}{c}0.0083 \\
(0.0152)\end{array}$ & $\begin{array}{c}0.1638^{* * * *} \\
(0.0362)\end{array}$ \\
\hline Water & $\begin{array}{l}-0.0572 \\
(0.0368)\end{array}$ & $\begin{array}{l}-0.0106 \\
(0.0130)\end{array}$ & $\begin{array}{c}-0.0636^{* *} \\
(0.0271)\end{array}$ & $\begin{array}{c}0.1144^{* * *} \\
(0.0199)\end{array}$ & $\begin{array}{c}0.0128 \\
(0.0231)\end{array}$ & $\begin{array}{l}-0.0125 \\
(0.0549)\end{array}$ \\
\hline Accessibility & $\begin{array}{c}0.0488^{* * *} \\
(0.0133)\end{array}$ & $\begin{array}{c}0.0070 \\
(0.0047)\end{array}$ & $\begin{array}{c}-0.0254^{* * * *} \\
(0.0098)\end{array}$ & $\begin{array}{l}-0.0011 \\
(0.0072)\end{array}$ & $\begin{array}{l}-0.0085 \\
(0.0083)\end{array}$ & $\begin{array}{l}-0.0184 \\
(0.0198)\end{array}$ \\
\hline Population density & $\begin{array}{l}0.0017^{* *} \\
(0.0008)\end{array}$ & $\begin{array}{c}-0.0005^{*} \\
(0.0003)\end{array}$ & $\begin{array}{l}-0.0001 \\
(0.0006)\end{array}$ & $\begin{array}{l}-0.0004 \\
(0.0004)\end{array}$ & $\begin{array}{l}-0.0003 \\
(0.0005)\end{array}$ & $\begin{array}{l}-0.0008 \\
(0.0012)\end{array}$ \\
\hline \multicolumn{7}{|l|}{ Household characteristics } \\
\hline Urban household & $\begin{array}{c}-0.0277^{* * *} \\
(0.0073)\end{array}$ & $\begin{array}{l}0.0068^{* * *} \\
(0.0026)\end{array}$ & $\begin{array}{l}-0.0016 \\
(0.0054)\end{array}$ & $\begin{array}{c}0.0027 \\
(0.0039)\end{array}$ & $\begin{array}{c}0.0074 \\
(0.0046)\end{array}$ & $\begin{array}{c}0.0193 \\
(0.0109)\end{array}$ \\
\hline Urban household head is farmer & $\begin{array}{c}0.0237^{* * *} \\
(0.0090)\end{array}$ & $\begin{array}{c}0.0017 \\
(0.0032)\end{array}$ & $\begin{array}{l}0.0120 \text { * } \\
(0.0066)\end{array}$ & $\begin{array}{l}-0.0002 \\
(0.0049)\end{array}$ & $\begin{array}{c}-0.0115 \text { ** } \\
(0.0056)\end{array}$ & $\begin{array}{c}-0.0306^{* *} \\
(0.0134)\end{array}$ \\
\hline Household size & $\begin{array}{c}0.0131^{* * *} \\
(0.0015)\end{array}$ & $\begin{array}{c}-0.0059^{* * *} \\
(0.0005)\end{array}$ & $\begin{array}{c}-0.0111^{* * * *} \\
(0.0011)\end{array}$ & $\begin{array}{c}-0.0045^{* * * *} \\
(0.0008)\end{array}$ & $\begin{array}{c}0.0072^{* * * *} \\
(0.0009)\end{array}$ & $\begin{array}{c}0.0073^{* * *} \\
(0.0022)\end{array}$ \\
\hline Dependency ratio & $\begin{array}{l}-0.0044 \\
(0.0073)\end{array}$ & $\begin{array}{c}0.0116^{* * * *} \\
(0.0026)\end{array}$ & $\begin{array}{c}0.0081 \\
(0.0053)\end{array}$ & $\begin{array}{c}0.0002 \\
(0.0039)\end{array}$ & $\begin{array}{c}0.0594^{* * * *} \\
(0.0045)\end{array}$ & $\begin{aligned}- & 0.0874^{* * * *} \\
& (0.0108)\end{aligned}$ \\
\hline $\begin{array}{c}\text { Ethnicity head } \\
\text { (northern mountain region) }\end{array}$ & $\begin{array}{c}0.0279 * * * \\
(0.0081)\end{array}$ & $\begin{array}{l}-0.0016 \\
(0.0028)\end{array}$ & $\begin{array}{c}0.0000 \\
(0.0059)\end{array}$ & $\begin{array}{c}0.0041 \\
(0.0044)\end{array}$ & $\begin{array}{c}-0.0124^{* *} \\
(0.0051)\end{array}$ & $\begin{array}{l}-0.0219 * \\
(0.0120)\end{array}$ \\
\hline Age head & $\begin{array}{c}0.0002 \\
(0.0002)\end{array}$ & $\begin{array}{l}0.0003^{* * * *} \\
(0.0001)\end{array}$ & $\begin{array}{l}0.0002 * \\
(0.0001)\end{array}$ & $\begin{array}{l}0.0003^{* * *} \\
(0.0001)\end{array}$ & $\begin{array}{l}-0.0003^{* * *} \\
(0.0001)\end{array}$ & $\begin{aligned}- & 0.0010^{* * * *} \\
& (0.0002)\end{aligned}$ \\
\hline $\begin{array}{l}\text { Gender head } \\
\quad(\text { male }=1)\end{array}$ & $\begin{array}{c}0.0002 \\
(0.0048)\end{array}$ & $\begin{array}{c}-0.0048^{* * * *} \\
(0.0017)\end{array}$ & $\begin{array}{l}0.0153^{* * *} \\
(0.0036)\end{array}$ & $\begin{array}{l}-0.0003 \\
(0.0026)\end{array}$ & $\begin{array}{c}-0.0169 * * * \\
(0.0030)\end{array}$ & $\begin{array}{l}-0.0031 \\
(0.0072)\end{array}$ \\
\hline Education head (2) & $\begin{array}{l}-0.0111 \\
(0.0070)\end{array}$ & $\begin{array}{l}-0.0039 \\
(0.0025)\end{array}$ & $\begin{array}{l}0.0097^{*} \\
(0.0051)\end{array}$ & $\begin{array}{c}0.0056 \\
(0.0038)\end{array}$ & $\begin{array}{c}0.0013 \\
(0.0044)\end{array}$ & $\begin{array}{l}-0.0017 \\
(0.0104)\end{array}$ \\
\hline Education head (3) & $\begin{array}{c}-0.0300^{* * *} \\
(0.0068)\end{array}$ & $\begin{array}{l}-0.0024 \\
(0.0024)\end{array}$ & $\begin{array}{c}0.0120 * * \\
(0.0050)\end{array}$ & $\begin{array}{c}0.0053 \\
(0.0037)\end{array}$ & $\begin{array}{l}0.0099 * * \\
(0.0042)\end{array}$ & $\begin{array}{c}0.0057 \\
(0.0101)\end{array}$ \\
\hline Education head (4) & $\begin{array}{c}-0.0458^{* * *} \\
(0.0078)\end{array}$ & $\begin{array}{c}-0.0059^{* * *} \\
(0.0027)\end{array}$ & $\begin{array}{c}0.0035 \\
(0.0057)\end{array}$ & $\begin{array}{c}0.0050 \\
(0.0042)\end{array}$ & $\begin{array}{l}0.0093 * \\
(0.0049)\end{array}$ & $\begin{array}{l}0.0361^{* * *} \\
(0.0116)\end{array}$ \\
\hline Education head (5) & $\begin{array}{c}-0.0607^{* * *} \\
(0.0102)\end{array}$ & $\begin{array}{c}-0.0104^{* * *} \\
(0.0036)\end{array}$ & $\begin{array}{l}-0.0046 \\
(0.0075)\end{array}$ & $\begin{array}{l}0.0128^{* * *} \\
(0.0055)\end{array}$ & $\begin{array}{c}0.0346^{* * * *} \\
(0.0064)\end{array}$ & $\begin{array}{c}0.0403^{* * *} \\
(0.0153)\end{array}$ \\
\hline Income quartile (2) & $\begin{array}{c}-0.0500^{* * *} \\
(0.0057)\end{array}$ & $\begin{array}{l}-0.0012 \\
(0.0020)\end{array}$ & $\begin{array}{l}0.0216^{* * *} \\
(0.0042)\end{array}$ & $\begin{array}{c}0.0029 \\
(0.0031)\end{array}$ & $\begin{array}{c}0.0030 \\
(0.0035)\end{array}$ & $\begin{array}{l}0.0267^{* * *} \\
(0.0084)\end{array}$ \\
\hline Income quartile (3) & $\begin{array}{c}-0.1041^{* * *} \\
(0.0062)\end{array}$ & $\begin{array}{c}-0.0077^{* * *} \\
(0.0022)\end{array}$ & $\begin{array}{c}0.0280^{* * * *} \\
(0.0046)\end{array}$ & $\begin{array}{l}-0.0004 \\
(0.0034)\end{array}$ & $\begin{array}{c}0.0118^{* * *} \\
(0.0039)\end{array}$ & $\begin{array}{c}0.0800^{* * *} \\
(0.0093)\end{array}$ \\
\hline Income quartile (4) & $\begin{array}{c}-0.1360 * * * \\
(0.0072)\end{array}$ & $\begin{array}{c}-0.0111^{* * *} \\
(0.0025)\end{array}$ & $\begin{array}{c}0.0283^{* * *} \\
(0.0053)\end{array}$ & $\begin{array}{l}-0.0018 \\
(0.0039)\end{array}$ & $\begin{array}{c}0.0132^{* * * *} \\
(0.0045)\end{array}$ & $\begin{array}{c}0.1136^{* * *} \\
(0.0107)\end{array}$ \\
\hline Drinking water source & & & & & & \\
\hline Tap water (Rural) & $\begin{array}{c}0.0025 \\
(0.0073)\end{array}$ & $\begin{array}{l}-0.0001 \\
(0.0026)\end{array}$ & $\begin{array}{c}0.0060 \\
(0.0053)\end{array}$ & $\begin{array}{c}-0.0159 * * * \\
(0.0039)\end{array}$ & $\begin{array}{c}-0.0033 \\
(0.0045)\end{array}$ & $\begin{array}{c}0.0177 \\
(0.0108)\end{array}$ \\
\hline Well (Urban) & $\begin{array}{c}-0.0214^{*} \\
(0.0121)\end{array}$ & $\begin{array}{c}-0.0109 * * \\
(0.0043)\end{array}$ & $\begin{array}{c}0.0241^{* * *} \\
(0.0089)\end{array}$ & $\begin{array}{l}-0.0036 \\
(0.0065)\end{array}$ & $\begin{array}{c}0.0078 \\
(0.0076)\end{array}$ & $\begin{array}{c}0.0075 \\
(0.0180)\end{array}$ \\
\hline Well (Rural) & $\begin{array}{c}0.0410^{* * * *} \\
(0.0131)\end{array}$ & $\begin{array}{l}0.0117^{* *} \\
(0.0046)\end{array}$ & $\begin{array}{l}-0.0149 \\
(0.0096)\end{array}$ & $\begin{array}{l}-0.0045 \\
(0.0071)\end{array}$ & $\begin{array}{l}-0.0128 \\
(0.0082)\end{array}$ & $\begin{array}{l}-0.0234 \\
(0.0196)\end{array}$ \\
\hline
\end{tabular}


Table 6. Cont.

\begin{tabular}{|c|c|c|c|c|c|c|}
\hline Variables & Cereals & $\begin{array}{l}\text { Fruit and } \\
\text { Vegetables }\end{array}$ & Meat & Fish & $\begin{array}{l}\text { Dairy } \\
\text { Products } \\
\text { and Eggs }\end{array}$ & FAFH \\
\hline Stream (Urban) & $\begin{array}{c}-0.0098 \\
(0.0102)\end{array}$ & $\begin{array}{l}-0.0005 \\
(0.0036)\end{array}$ & $\begin{array}{l}0.0145 * \\
(0.0075)\end{array}$ & $\begin{array}{l}-0.0026 \\
(0.0055)\end{array}$ & $\begin{array}{c}0.0011 \\
(0.0064)\end{array}$ & $\begin{array}{c}0.0010 \\
(0.0153)\end{array}$ \\
\hline Stream (Rural) & $\begin{array}{c}0.0652^{* * *} \\
(0.0117)\end{array}$ & $\begin{array}{c}-0.0023 \\
(0.0041)\end{array}$ & $\begin{array}{c}-0.0170^{* *} \\
(0.0086)\end{array}$ & $\begin{array}{c}-0.0138^{* *} \\
(0.0063)\end{array}$ & $\begin{array}{c}-0.0123 \\
(0.0073)\end{array}$ & $\begin{array}{c}-0.0308 \text { * } \\
(0.0174)\end{array}$ \\
\hline $\begin{array}{c}\text { Time and administrative } \\
\text { are dummies } \\
\text { Province dummies } \\
\text { Period of surveying }\end{array}$ & Yes & Yes & Yes & Yes & Yes & Yes \\
\hline June & $\begin{array}{c}-0.0096 * \\
(0.0053)\end{array}$ & $\begin{array}{l}0.0032 * \\
(0.0019)\end{array}$ & $\begin{array}{c}-0.0002 \\
(0.0039)\end{array}$ & $\begin{array}{c}0.0023 \\
(0.0029)\end{array}$ & $\begin{array}{c}0.0072^{* *} \\
(0.0033)\end{array}$ & $\begin{array}{c}-0.0072 \\
(0.0079)\end{array}$ \\
\hline September & $\begin{array}{c}-0.0198^{* * * *} \\
(0.0052)\end{array}$ & $\begin{array}{l}-0.0009 \\
(0.0018)\end{array}$ & $\begin{array}{l}0.0070 \text { * } \\
(0.0039)\end{array}$ & $\begin{array}{c}0.0041 \\
(0.0028)\end{array}$ & $\begin{array}{l}0.0061^{*} \\
(0.0033)\end{array}$ & $\begin{array}{c}0.0031 \\
(0.0078)\end{array}$ \\
\hline December & $\begin{array}{c}-0.0217^{* * *} \\
(0.0053)\end{array}$ & $\begin{array}{l}-0.0018 \\
(0.0019)\end{array}$ & $\begin{array}{c}0.0017 \\
(0.0039)\end{array}$ & $\begin{array}{c}0.0023 \\
(0.0028)\end{array}$ & $\begin{array}{c}0.0019 \\
(0.0033)\end{array}$ & $\begin{array}{c}0.0186^{* *} \\
(0.0079)\end{array}$ \\
\hline Constant & $\begin{array}{c}0.3249 * * * \\
(0.0161)\end{array}$ & $\begin{array}{c}0.1084^{* * *} \\
(0.0057)\end{array}$ & $\begin{array}{c}0.2106^{* * *} \\
(0.0118)\end{array}$ & $\begin{array}{c}0.0713^{* * *} \\
(0.0087)\end{array}$ & $\begin{array}{c}0.0354^{* * *} \\
(0.0101)\end{array}$ & $\begin{array}{c}0.1173^{* * *} \\
(0.0240)\end{array}$ \\
\hline Observations & 3759 & 3759 & 3759 & 3759 & 3759 & 3759 \\
\hline R-squared & 0.4411 & 0.1599 & 0.1494 & 0.2489 & 0.1634 & 0.2423 \\
\hline
\end{tabular}

Standard errors in parentheses. ${ }^{* * *} p<0.01,{ }^{* *} p<0.05,{ }^{*} p<0.1$. ${ }^{*}$ See Appendix B for the results of the province dummies.

\subsection{Landscape Characteristics}

The district landscape characteristics which are included in the analysis are linked to the exposure level of environmental pollution and health. Households living in districts in which the urbanization rate is higher and in areas with a higher share of surface water are more potentially exposed to environmental pollution than households living in districts in which the urbanization rate is lower and districts with a lower share of surface water.

The households living in a district in which the urbanization rate is higher had a lower share of cereals as well as meat and higher shares of fruit and vegetables, fish, and food consumed away from home. Households living in a district in which the share of surface water is higher had a lower share of meat consumption and a higher share of fish consumption.

If the exposure level of environmental pollution to the consumption shares were linked, the results showed us that the consumption share of cereals decreased when households lived in districts with a higher urbanization rate. This indicates that households potentially exposed to higher environmental pollution consumed less cereals. Moreover, the results suggested that households consumed less meat when living in districts with a higher urbanized share and a high share of surface water. Hence, the households which are identified as high exposure profile consumed less meat.

Households consumed more fish when they were living in an area with a large share of surface water and consumed less fish when living in a district with a higher urbanization rate. The higher share of surface waters suggests a higher fish stock. However, the danger of waterborne diseases caused by the exposure to environmental pollution also increases in case households were living in districts with a higher share of surface water.

The consumption of fruit and vegetables increased for households living in urbanized districts. These households living in the urbanized districts face more danger to health issues due to emission on toxic substances compared to households living in less urbanized districts. The industrial pollution could contaminate the produced fruit and vegetables in the urban areas.

The FAFH consumption increased for households living in districts with a higher urbanization share due to the availability of food outlets. The urban households risk more danger to foodborne diseases caused by environmental pollution in the food they consume away from home. 
The accessibility to a city influenced the share of cereals positively and the share of meat negatively. Households living in more densely populated areas showed a higher share of cereals and a lower share of fruit and vegetables. Very densely populated areas in cities are often the poorer neighborhoods due to high prices of land. The poorer households in these densely populated areas spend less money on food consumption and therefore will consume cheaper food products such as cereals and less expensive food products such as fruit and vegetables.

\subsection{Household Characteristics}

The results in Table 6 show that households living in urban areas had a lower share of cereals in their food consumption, a higher share of fruit and vegetables, and a higher share of food consumed away from home. Households living in urban areas were probably less often involved in agricultural practices and hence were less involved in producing their own food products. Moreover, household in urban areas have higher accessibility to food outlets (shops, restaurants, and markets) where people can consume prepared or takeaway meals. This is supported by the results that people in urban areas have a higher share of food consumed away from home. In urban areas, the income and education level were relatively higher compared to rural areas which could explain the higher share of fruit and vegetables and lower share of cereals.

If an urban household is involved in agriculture, the household had a higher share for cereals and meat and a lower share for dairy products and eggs and food consumed away from home. These households produced more of their own food. which could explain the higher shares for cereals and meat. The lower share for food consumed away from home seems to confirm the higher share of home production of food products.

The household size showed significant effects for all food consumption categories. For cereals, dairy products and eggs, and food consumed away from home, the coefficients of household size were positive, which means the larger the household, the higher the share of the food consumption categories. The coefficients of household size in the equations of the shares of fruit and vegetables, meat, and fish were negative. These categories are often seen as more luxury food products.

Households with a higher dependency ratio had a higher share of fruit and vegetables and dairy products and eggs, and a lower share of food consumed away from home. This indicates that larger households attempt to provide their children with a healthy diet consuming more fruit and vegetables as well as dairy products and eggs. The share of food away from home could be lower because it is more convenient (both time- and pricewise) to consume a meal at home if your household consists of multiple children and or elderly people.

The age of the head of the household showed many significant results for the different food consumption categories. The shares of fruit and vegetables, meat, and fish showed a positive relationship, so that the shares increased with the age of the head. The coefficient of the dependency ratio was negative for the equations of the shares of dairy products and eggs and food away from home.

Education and income seemed to influence the share of most food consumption categories. Education is divided into five different classes and the effect of income is calculated per income quartile. The categories with the lowest level of education and income were used as reference categories.

The coefficient for the dummy variable of household heads that completed primary education was positive in the share of meat equation. The education classes for lower secondary education, higher secondary education, and college or higher showed all negative results for the share of cereals. The higher the education class, the smaller the magnitude of the negative effect. This indicates that with a higher completed education the negative effect on the share of cereals decreases. The education classes for higher secondary education and college or higher both show a negative effect. The negative effect is larger for household heads with a college or higher education. The education classes for no education 
and primary education both show a positive effect. The effect is larger for primary education. In the equation of the share of fish, there was a positive result for household head with college or higher education. The share of dairy products and eggs showed positive effects for lower secondary education, higher secondary education, and college or higher completed education. Lastly, the education classes higher secondary and college or higher showed both a positive result. The positive result is larger for college or higher completed education level.

The coefficients of the income quartiles showed negative coefficients for the equations of the share of cereals. The coefficients for income were $-0.05,-0.1041$, and -0.1360 for the income quartiles 2, 3, and 4 respectively. Income quartile 3 and 4 showed a negative effect for the share of fruit and vegetables and for dairy products and eggs. For the share of meat and the share of food consumed away from home, the coefficient for all three income quartiles were positive.

\subsection{Drinking Water Sources}

For rural households using tap water as primary water source, the households had a lower share of fish. In urban areas, households with a well as their primary drinking water source had a lower share of cereals as well as fruit and vegetables, while they had a higher share of meat. Households living in urban areas that use a well as their primary water source most likely do not live in the most densely populated urban areas. At the outskirts of the urban areas, these households could keep their own livestock which could explain their higher share of meat consumption.

Households living in rural areas that use a well as their primary water source had a higher share for cereals and fruit and vegetables. If the household does not have access to tap water, this could indicate that the household lives in a remote area. Households living in more remote areas are more likely to be farming households producing cereals and maybe also fruit and/or vegetables. Moreover, households living remotely largely depend on sales of agricultural products for their income, and usually the average income is lower in rural areas. Especially the higher share of cereals could be explained by the higher availability of cereals in rural areas.

For urban households using a well as primary water source, only the share of meat showed a significant effect. These households have a higher share for meat consumption. Urban households which use a stream as their primary water source, are probably located in peri-urban areas, where they can keep their own livestock. Rural households using a stream as primary water source have a higher share of cereals and a lower share of meat, fish, dairy products and eggs, as well as food consumed away from home.

\subsection{Province and Time}

In the specification, dummy variables for the different provinces and months are included. The results of the individual provinces are highlighted in Appendix B. Dummy variables for the period of surveying is carried out are included in the model as well. In case the survey was carried out in June, September, or December, the share of cereals decreased. The negative effect was largest in December. The share of fruit and vegetables and dairy products and eggs showed a positive significant effect for June. In December, the share of food consumed away from home showed a positive effect.

\section{Discussion}

In this section, we discuss the results in more detail and compare them to previous studies. Moreover, limitations to the study are addressed.

\subsection{Cereals}

Changes in income over time have shown to influence the food consumption patterns of consumers. For example, in China, an increase in income in the late 1990s led to a decrease in the food consumption value of cereals, mainly rice [42]. Furthermore, results of 
the VHLSS of 2006 indicated a lower share of cereals of the food expenditures for higher income quantiles [30]. Therefore, the results of this paper showed a negative relation between increases in income and the share of consumption value for cereals.

Compared to the results of the VHLSS of 2006, the data of 2014 also indicated a lower share of cereals among urban households. In this paper, the effects of the households being a farmer on the share of the different food consumption categories were estimated. Urban households involved in agriculture had a higher share of cereals. The data of the VHLSS of 2006 showed a higher share of cereals among farmers compared to non-farmers, however this estimation is not specified for urban households [30].

Ethnic minorities in Vietnam had a higher share of cereals compared to the ethnic majority (Kihn) in the 2006 VHLSS dataset. Furthermore, we conclude that ethnic minorities in the northern mountain region had a higher share of cereals. Minorities in Vietnam live more often in rural areas and are therefore more often involved in agricultural practices [30].

\subsection{Fruit and Vegetables}

A study in Vietnam conducted in 2009 and 2010 concluded that urban households consume more fruit and vegetables compared to rural households [43]. Results of this study also indicated a higher share for fruit and vegetables among urban households.

This same study conducted in 2009 and 2010 also concluded that income level and education level have positive effects on the consumption value of fruit and vegetables. The results of this paper concluded conflicting effects. Both education and income had a negative effect on the share of fruit and vegetable consumption. The negative effect increased for higher education levels and income levels.

A study on rural households in Vietnam in 2005 showed that men less often consumed fruit compared to women [44]. The results of this paper showed that male-headed household had a lower share of fruit and vegetables as well.

\subsection{Meat}

The results of the SURE showed that the share of meat of the food consumption value is influenced by different household characteristics. Comparing the results of this paper to the results of the VHLSS of 2010 show many similar results. Data from the VHLSS of 2010 showed that an increase in household size results in a lower consumption of meat. Furthermore, households with male heads, households with a household head with a higher age, households living in urban areas, households with a household head with a higher completed education, and households with a higher income consumed more meat [45]. These similar results show the consistency in the food consumption value of households in case of meat consumption.

The parameter estimation of urban for the household characteristics is not significant. This means there is no statistically significant difference between rural and urban households in their consumption value for meat. However, the parameter estimation of urban for the district characteristics was significant and negative.

\subsection{Fish}

In a previous study among Asian countries, the income of the household, the location of the household (rural or urban), and the fact if the household was involved in agriculture (fish farmer) contributed to the fish consumption level of a household [46]. Household size, the age of the household head, and education showed significant results in this study, but not in the previous study among different Asian countries. 


\subsection{Dairy Products and Eggs}

A previous study based on the VHLSS 2010 results showed a positive effect of the decision to consume dairy products if the household size increases, and a negative effect for the expenditure level if the household size increases. If the household size increases, more households consumed dairy products, but their total expenditures on dairy products decreased [47]. Based on the VHLSS of 2014, this study showed a positive effect of the increase in household size and consumption share of dairy products and eggs.

A study on rural households in Vietnam on milk consumption concluded that households consisting of more children and elders spent a higher share of their budget on milk consumption. Children and elderly are the more prioritized persons for milk consumption due to health reasons. The same results were shown for this paper.

The age of the household head negatively influenced consumption of dairy products and eggs. A higher age of the household head could indicate that the household does not consist of a young couple with young children, but rather a household with either children of an older age or the children already moved out of their parents' house. As was argued for the dependency ratio, that parents prioritize children for milk consumption could lead to a lower share of dairy products and eggs in case the household head's age increases.

Moreover, a higher completed education level and income level results in a higher expenditure on dairy products and eggs. The results of the VHLSS of 2010 and the study of rural households in Vietnam showed the same positive effects of education level and income [48].

\subsection{Food away from Home (FAFH)}

Studies concluded that households living in urban areas consume more food away from home compared to households in rural areas. The higher availability of food outlets where people have access to cheap and quickly prepared ready-made meals results in a higher intake of food consumed away from home in urban areas [42,49].

The data of the VHLSS of 2006 showed that farmer households had on average a lower share of FAFH expenditures compared to non-farmer households [30].

In addition, a higher income leads to a higher consumption value of food consumed away from home. The results of this paper showed a positive impact of income on the share of food consumed away from home. For higher income quartiles, the positive coefficient increases.

\subsection{Limitations}

Obviously, to explore the impact of environmental pollution on the food system and health, more accurate information and data is required. However, detailed data are unavailable. In our analysis, we also investigated the relationship between environmental pollution, food consumption, and health outcomes. The lack of suitable data on health expenditure made it impossible to measure the actual impact of foodborne diseases on the health care expenditures of households.

The district land cover share variables which were included in the analysis were only available for the three northern districts of Vietnam, which might limit the external validity of this study. Moreover, the data for the district variables are not collected as frequently as the national household data (VHLSS), therefore the data used in this study are not the most recent dataset of the VHLSS and might be outdated. In addition, since a comprehensive survey on surface water quality is not available in Vietnam, variables such as the urbanization rate and share of surface water per district were operationalized as proxies for water pollution. The results of the districts characteristics are therefore only an indication for potential exposure to toxic hazards. 


\section{Conclusions}

This study discussed the environmental pressures of food consumption in Vietnam using a food system approach. Environmental pressures in the food system are not only related to the diets and the value chains but might also be affected by exposure to toxic hazards due to water pollution by agriculture and manufacturing industries. In Vietnam, water pollution from these activities are still very widespread, although the exact magnitude is unknown or inaccurate. Therefore, we proposed to use proxies for pollution based on spatial information - the so-called landscape characteristics-reflecting certain profiles of potential water pollution. With the food consumption information from the VHLSS 2014 and spatial data, we explained the drivers of food consumption categories. The results indicated that urban household have a different food consumption pattern than rural households. Based on the landscape characteristics, households in urban areas eat more fruit and vegetables as well as fish. Since these food categories are usually more prone to food safety risks such as residues of pesticides of waterborne diseases, urban households in areas with higher degrees of urbanization even face a double environmental burden: not only do they consume more food with food safety risks, but they also are potentially more exposed to toxic hazards through water consumption. Our findings might raise a concern for policy makers steering consumers in Vietnam to healthier diets that there are combined environmental effects to consider as well.

The results of this study are indicative because we used landscape characteristics to proxy the environmental pollution effects on food consumption. Despite this fact, the results showed significant linkages for further investigation. It requires more research on the details of the complex relationship between environmental pollution of water resources and the food system. Most likely, the data requirements become more severe. However, since the effect of polluted food and health care expenditures is discussed in various studies but not specifically for Vietnam, it is recommended to integrate specified health care expenditures in future research on environmental pollution and food consumption in Vietnam.

Author Contributions: Conceptualization, V.L. and V.D.; methodology, V.L., M.M., V.D., and A.S.; data preparation of household survey, M.M.; data preparation of spatial data, V.D.; data analysis, M.M. and A.S.; writing — original draft preparation, V.L., V.D., and A.S.; writing—review and editing, V.L., V.D., M.M., and A.S. All authors have read and agreed to the published version of the manuscript.

Funding: This study was funded by the CGIAR research program on Agriculture for Nutrition and Health (grant number CRP21-OB2-2018/2019).

Institutional Review Board Statement: Not applicable.

Informed Consent Statement: Not applicable.

Data Availability Statement: Not applicable.

Acknowledgments: The authors would like to thank Thom Achterbosch for his discussions on the earlier versions of this paper.

Conflicts of Interest: The authors declare no conflict of interest. 


\section{Appendix A}

Table A1. Food items, food groups, and the price of $1000 \mathrm{kcals}$ (1000 VND) caloric intake per value of consumption.

\begin{tabular}{|c|c|c|c|c|}
\hline Categories & Groups & Food Code & Food Items & $\begin{array}{l}\text { Price of } 1000 \mathrm{kcal} \\
\quad(1000 \text { VND) }\end{array}$ \\
\hline \multirow{9}{*}{ Cereals } & \multirow[t]{2}{*}{ Rice } & 101 & $\begin{array}{l}\text { Plain rice, including fragrant and } \\
\text { speciality rice }\end{array}$ & 1.10 \\
\hline & & 102 & Sticky rice & 1.88 \\
\hline & \multirow{7}{*}{ Other staples } & 103 & Maize & 1.33 \\
\hline & & 104 & Cassava & 1.98 \\
\hline & & 105 & Potato of various kinds & 3.73 \\
\hline & & 106 & Wheat grains, bread, wheat powder & 3.45 \\
\hline & & 107 & $\begin{array}{l}\text { Flour noodle, instant rice } \\
\text { noodle/porridge }\end{array}$ & 3.69 \\
\hline & & 108 & Fresh rice noodle, dried rice noodle & 3.02 \\
\hline & & 109 & Vermicelli & 10.03 \\
\hline \multirow{7}{*}{ Meat } & \multirow{7}{*}{ Meat } & 110 & Pork & 9.79 \\
\hline & & 111 & Beef & 47.69 \\
\hline & & 112 & Buffalo meat & 52.71 \\
\hline & & 113 & Chicken meat & 15.19 \\
\hline & & 114 & Duck and other poultry meat & 7.10 \\
\hline & & 115 & Other types of meat & 12.50 \\
\hline & & 116 & Processed meat & 12.36 \\
\hline \multirow{4}{*}{ Fish } & \multirow{3}{*}{ Fish and seafood } & 118 & Fresh shrimps, fish & 21.80 \\
\hline & & 119 & Dried and processed shrimps, fish & 9.67 \\
\hline & & 120 & $\begin{array}{l}\text { Other aquatic products and seafood } \\
\text { (crabs, snails) }\end{array}$ & 22.35 \\
\hline & Tofu & 122 & Tofu & 6.01 \\
\hline \multirow{11}{*}{ Fruit and vegetables } & \multirow{7}{*}{ Vegetables } & 124 & Beans of various kinds & 15.00 \\
\hline & & 125 & Fresh peas of various kinds & 7.04 \\
\hline & & 126 & Morning glory vegetables & 9.18 \\
\hline & & 127 & Kohlrabi & 8.41 \\
\hline & & 128 & Cabbage & 10.11 \\
\hline & & 129 & Tomato & 18.25 \\
\hline & & 130 & Other vegetables & 9.66 \\
\hline & \multirow{4}{*}{ Fruits } & 131 & Orange & 23.61 \\
\hline & & 132 & Banana & 4.01 \\
\hline & & 133 & Mango & 9.99 \\
\hline & & 134 & Other fruits & 8.08 \\
\hline \multirow{4}{*}{ Dairy products and eggs } & \multirow{4}{*}{ Dairy } & 141 & Condensed milk, milk powder & 19.50 \\
\hline & & 142 & Ice cream, yoghurt & 18.64 \\
\hline & & 143 & Fresh milk & 18.55 \\
\hline & & 120 & Eggs of poultry & 12.16 \\
\hline
\end{tabular}


Table A1. Cont.

\begin{tabular}{|c|c|c|c|c|}
\hline Categories & Groups & Food Code & Food Items & $\begin{array}{l}\text { Price of } 1000 \mathrm{kcal} \\
\text { (1000 VND) }\end{array}$ \\
\hline Food away from home & Food away from home & 153 & $\begin{array}{l}\text { Outdoor meals and drinks } \\
\text { (breakfast, lunch, dinner) }\end{array}$ & 3.56 \\
\hline \multirow[t]{16}{*}{ Other } & Other & 117 & Lard cooking oil & 1.51 \\
\hline & & 123 & Peanuts, sesame & 2.41 \\
\hline & & 135 & Fish sauce & 14.37 \\
\hline & & 136 & Salt & \\
\hline & & 137 & MSG & \\
\hline & & 138 & Glutamate & \\
\hline & & 139 & Sugar, molasses & 1.45 \\
\hline & & 140 & Confectionery & 5.19 \\
\hline & & 144 & Alcohol of various kinds & 13.98 \\
\hline & & 145 & Beer of various kinds & 69.75 \\
\hline & & 147 & Instant coffee & 10.64 \\
\hline & & 148 & Coffee powder & 9.42 \\
\hline & & 149 & Instant tea powder & \\
\hline & & 150 & Other dried tea & \\
\hline & & 152 & $\begin{array}{c}\text { Betel leaves, areca nuts, lime, } \\
\text { betel pieces }\end{array}$ & \\
\hline & & 154 & Other food and drinks & 3.39 \\
\hline
\end{tabular}

Notes: Mentioned prices of $1000 \mathrm{kcal}$ are the averages for the whole population. In practice each household faces its own household price, based on e.g., region, taste, quality of the product, and availability of products. However, these average prices can function as a reference price. Source: Table is based on data from (Trinh, 2017).

\section{Appendix B}

Table A2. Results of province dummy coefficients in addition extended SURE regression results of the province dummies.

\begin{tabular}{|c|c|c|c|c|c|c|}
\hline $\begin{array}{l}\text { Province } \\
\text { Dummies }\end{array}$ & Cereals & $\begin{array}{l}\text { Fruit and } \\
\text { Vegetables }\end{array}$ & Meat & Fish & $\begin{array}{l}\text { Dairy Products } \\
\text { and Eggs }\end{array}$ & FAFH \\
\hline \multicolumn{7}{|c|}{ Northeast (Đông Bắc Bộ) where Hà Giang province is the reference } \\
\hline Bắc Giang & $0.0221 *$ & $-0.0191^{* * *}$ & -0.0004 & -0.0094 & -0.0090 & 0.0267 \\
\hline Hà Giang & -0.0252 & 0.0035 & 0.0173 & -0.0122 & $-0.0191 *$ & -0.0020 \\
\hline Bắc Kạn & 0.0117 & $-0.0206^{* * *}$ & -0.0120 & -0.0025 & $-0.0220 * *$ & $0.0441 *$ \\
\hline Cao Bằng & $-0.0451 * * *$ & $-0.0113 *$ & $-0.0215 *$ & $-0.0248^{* * *}$ & -0.0168 & $0.1065^{* * *}$ \\
\hline Lạng Sơn & -0.0074 & -0.0024 & $-0.0369^{* * *}$ & $-0.0147^{*}$ & -0.0174 * & $0.0579^{* *}$ \\
\hline Phú Thọ & $0.0412^{* * *}$ & $-0.0313^{* * *}$ & -0.0111 & 0.0025 & 0.0062 & 0.0105 \\
\hline Quảng Ninh & -0.0081 & -0.0069 & $-0.0596^{* * *}$ & $0.0976^{* * *}$ & $-0.0321^{* * *}$ & 0.0231 \\
\hline Thái Nguyên & $0.0278^{* *}$ & $-0.0104^{* *}$ & $0.0198^{* *}$ & $-0.0222^{* * *}$ & -0.0038 & 0.0005 \\
\hline Tuyên Quang & 0.0186 & $-0.0122^{* *}$ & $0.0299 * * *$ & -0.0128 & $-0.0151 *$ & -0.0021 \\
\hline \multicolumn{7}{|c|}{ Northwest (Tây Bắc Bộ) where pProvince Điện Biên is the refence } \\
\hline Hòa Bình & $0.0478^{* * *}$ & $-0.0144^{* * *}$ & $-0.0389^{* * *}$ & -0.0041 & $-0.0177^{*}$ & 0.0393 * \\
\hline Lai Châu & $0.0411^{* *}$ & $-0.0126^{* *}$ & -0.0147 & -0.0021 & $-0.0399^{* * *}$ & 0.0358 \\
\hline Lào Cai & $0.0405^{* * *}$ & -0.0041 & $-0.0296^{* *}$ & 0.0086 & $-0.0189 *$ & 0.0258 \\
\hline Sơn La & -0.0078 & $-0.0193^{* * *}$ & $0.0442 * * *$ & $0.0172 * *$ & $-0.0288^{* * *}$ & 0.0002 \\
\hline Yên Bái & -0.0084 & -0.0053 & -0.0089 & 0.0129 * & -0.0091 & 0.0332 \\
\hline
\end{tabular}


Table A2. Cont.

\begin{tabular}{|c|c|c|c|c|c|c|}
\hline $\begin{array}{l}\text { Province } \\
\text { Dummies }\end{array}$ & Cereals & $\begin{array}{l}\text { Fruit and } \\
\text { Vegetables }\end{array}$ & Meat & Fish & $\begin{array}{l}\text { Dairy Products } \\
\text { and Eggs }\end{array}$ & FAFH \\
\hline \multicolumn{7}{|c|}{ Red River Delta (Đồng Bằng Sông Hồng) where the municipality of Hà Nội is the reference } \\
\hline Bắc Ninh & 0.0069 & 0.0019 & 0.0012 & -0.0059 & 0.0113 & -0.0034 \\
\hline Hà Nam & $0.0528^{* * *}$ & $-0.0263^{* * *}$ & $-0.0279 * * *$ & $-0.0152^{* *}$ & $-0.0201^{* *}$ & $0.0507^{* *}$ \\
\hline Hải Dương & 0.0176 & $-0.0163^{* * *}$ & -0.0035 & $0.0286^{* * *}$ & $-0.0262^{* * *}$ & 0.0004 \\
\hline Hải Phòng & -0.0014 & $-0.0072 *$ & $-0.0464^{* * *}$ & $0.0570^{* * *}$ & $-0.0283^{* * *}$ & $0.0528^{* * *}$ \\
\hline Hưng Yên & $0.0489 * * *$ & $-0.0102 * *$ & 0.0006 & $-0.0145^{* *}$ & $-0.0144^{*}$ & -0.0052 \\
\hline Nam Định & $0.0610^{* * *}$ & $-0.0230^{* * *}$ & $-0.0487^{* * *}$ & $0.0223^{* * *}$ & -0.0089 & 0.0160 \\
\hline Ninh Bình & $0.0354^{* * *}$ & $-0.0275^{* * *}$ & $-0.0342^{* * *}$ & $0.0172^{* *}$ & $-0.0209^{* * *}$ & $0.0499^{* * *}$ \\
\hline Thái Bình & $0.0309^{* * *}$ & $-0.0181^{* * *}$ & $-0.0440^{* * *}$ & $0.0359^{* * *}$ & $-0.0231^{* * *}$ & 0.0294 * \\
\hline Vĩnh Phúc & -0.0013 & $-0.0209^{* * *}$ & $-0.0290^{* * *}$ & $-0.0171^{* *}$ & $0.0226^{* * *}$ & $0.0577^{* * *}$ \\
\hline \multicolumn{7}{|c|}{ North Central Coast (Bắc Trung Bộ) } \\
\hline Hà Tĩnh & $0.0437^{* * *}$ & $-0.0458^{* * *}$ & $-0.0288^{* *}$ & $0.0419^{* * *}$ & -0.0110 & 0.0073 \\
\hline Nghệ An & $0.0410^{* * *}$ & $-0.0270^{* * *}$ & $-0.0333^{* * *}$ & $0.0338^{* * *}$ & $-0.0243^{* * *}$ & 0.0138 \\
\hline Quảng Bình & $0.0518^{* * *}$ & -0.0096 & -0.0133 & 0.0044 & $-0.0332^{* * *}$ & 0.0203 \\
\hline Thanh Hóa & $0.0592^{* * *}$ & $-0.0290^{* * *}$ & $-0.0595^{* * *}$ & $0.0384^{* * *}$ & $-0.0168^{* *}$ & 0.0169 \\
\hline
\end{tabular}

\section{References}

1. WHO. Food Safety. Available online: https://www.who.int/en/news-room/fact-sheets/detail/food-safety (accessed on 23 March 2020).

2. $\quad$ van Berkum, S.; Dengerink, J.; Ruben, R. The Food Systems Approach: Sustainable Solutions for a Sufficient Supply of Healthy Food; Economic Research Memorandum; Wageningen Economic Research: The Hague, The Netherlands, 2018; p. 32.

3. Berkowitz, S.A.; Seligman, H.K.; Basu, S. Impact of Food Insecurity and SNAP Participation on Healthcare Utilization and Expenditures; University of Kentucky Center for Poverty Research Discussion Paper Series: Lexington, KY, USA, 2017.

4. Tarasuk, V.; Cheng, J.; de Oliveira, C.; Dachner, N.; Gundersen, C.; Kurdyak, P. Association between household food insecurity and annual health care costs. CMAJ 2015, 187. [CrossRef] [PubMed]

5. World Bank. Food Safety Risk Management in Vietnam: Challenges and Opportunities; World Bank Group: Hanoi, Vietnam, $2017 ;$ p. 92.

6. Nguyen-Viet, H.; Tuyet-Hanh, T.T.; Unger, F.; Dang-Xuan, S.; Grace, D. Food safety in Vietnam: Where we are at and what we can learn from international experiences. Infect. Dis. Poverty 2017, 6. [CrossRef]

7. WHO. WHO Estimates of the Global Burden of Foodborne Diseases; WHO: Geneva, Switzerland, 2015; ISBN 9789241565165.

8. Van Hoi, P.; Mol, A.P.J.; Oosterveer, P.; van den Brink, P.J. Pesticide distribution and use in vegetable production in the Red River Delta of Vietnam. Renew. Agric. Food Syst. 2009, 24, 174-185. [CrossRef]

9. Hoi, P.V.; Mol, A.P.J.; Oosterveer, P.; van den Brink, P.J.; Huong, P.T.M. Pesticide use in Vietnamese vegetable production: A 10-year study. Int. J. Agric. Sustain. 2016, 14, 325-338. [CrossRef]

10. Van Hoi, P.; Mol, A.; Oosterveer, P. State governance of pesticide use and trade in Vietnam. NJAS Wagening. J. Life Sci. 2013, 67, 19-26. [CrossRef]

11. Linderhof, V.; Sonneveld, A.; Diogo, V.; Meeske, M. Food Landscape Vietnam; Wageningen Economic Research: The Hague, The Netherlands, 2020.

12. Dasgupta, S.; Meisner, C.; Wheeler, D.; Xuyen, K.; Thi Lam, N. Pesticide poisoning of farm workers-implications of blood test results from Vietnam. Int. J. Hyg. Environ. Health 2007, 210, 121-132. [CrossRef] [PubMed]

13. Berg, H. Pesticide use in rice and rice-fish farms in the Mekong Delta, Vietnam. Crop Prot. 2001, 20, 897-905. [CrossRef]

14. Sebesvari, Z.; Le, H.T.T.; Toan, P.V.; Arnold, U.; Renaud, F.G. Agriculture and Water Quality in the Vietnamese Mekong Delta. In The Mekong Delta System; Springer Environmental Science and Engineering; Springer: Dordrecht, The Netherlands, 2012; pp. 331-361. ISBN 978-94-007-3961-1.

15. UNEP. Integrated Assessment of the Impact of Trade Liberalization: A Country Study on the Viet Nam Rice Sector; United Nations Environment Programme: Geneva, Switzerland, 2005; p. 80.

16. Hach, C.V.; Tan, P.S. Study on site-specific nutrient management (SSNM) for high-yielding rice in the Mekong Delta. Omonrice 2007, 9, 152.

17. Soong, J. Soil Fertility and Changes in Fertilizer Use for Intensive Rice Cultivation in the Red River Delta and Mekong Delta of Vietnam. In Independent Study Project (ISP) Collection; Oberlin College: Oberlin, OH, USA, 2006.

18. Van Hoi, P.; Mol, A.P.J.; Oosterveer, P.J.M. Market governance for safe food in developing countries: The case of low-pesticide vegetables in Vietnam. J. Environ. Manag. 2009, 91, 380-388. [CrossRef] [PubMed] 
19. World Bank. Review and Analysis of the Pollution Impacts from Vietnamese Manufacturing Sectors; Internation Bank for Reconstruction and Development/World Bank: Hanoi, Vietnam, 2008.

20. Khai, H.V.; Yabe, M. Impact of Industrial Water Pollution on Rice Production in Vietnam. Int. Perspect. Water Qual. Manag. Pollut. Control 2013. [CrossRef]

21. Hung, P.T.; Tuan, B.A.; Chinh, N.T. The Impact of Trade Liberalization on Industrial Pollution: Empirical Evidence from Vietnam; EEPSEA Research Report; Economy and Environment Program for Southeast Asia (EEPSEA): Ho Chi Minh City, Vietnam, 2016.

22. Thong, L.Q.; Ngoc, A. Incentives for Wastewater Management in Industrial Estates in Vietnam; EEPSEA Research Report rr2004084; Economy and Environment Program for Southeast Asia (EEPSEA): Ho Chi Minh City, Vietnam, 2004.

23. Tuyet-Hanh, T.T.; Long, T.K.; Van Minh, H.; Huong, L.T.T. Longitudinal Household Trends in Access to Improved Water Sources and Sanitation in Chi Linh Town, Hai Duong Province, Viet Nam and Associated Factors. Aims Public Health 2016, 3, 880-890. [CrossRef]

24. Chau, N.D.G.; Sebesvari, Z.; Amelung, W.; Renaud, F.G. Pesticide pollution of multiple drinking water sources in the Mekong Delta, Vietnam: Evidence from two provinces. Environ. Sci. Pollut. Res. Int. 2015, 22, 9042-9058. [CrossRef]

25. Viet Nam Multiple Indicator Cluster Survey 2014, Final Report; General Statistics Office, UNICEF: Ha Noi, Vietnam, 2015.

26. Agbola, F.W. Estimating The Demand For Food And Non-Food Items Using An Almost Ideal Demand System Modelling Approach. In Proceedings of the 44th Annual Conference of the Australian Agricultural and Resource Economics Society, Sydney, Australia, 23-25 January 2000; p. 14.

27. Akinleye, S.O.; Rahji, M.A. Nutrient elasticities among Nigerian households differentiated by income. Agrekon 2007, 46, 274-288. [CrossRef]

28. Burger, R.; Coetzee, W.; Kreuser, F.; Rankin, N. Income and Price Elasticities of Demand in South Africa: An Application of the Linear Expenditure System; WIDER Working Paper; World Institute for Development Economics Research (WIDER): Helsinki, Finland, 2015 ; p. 33.

29. Le, C.Q. An empirical study of food demand in Vietnam. Asean Econ. Bull. 2008, 25, 283-292. [CrossRef]

30. Hoang, L.V. Estimation of Food Demand from Household Survey Data in Vietnam; DEPOCEN working paper series; Center for Agricultural Policy, Institute of Policy and Strategy for Agriculture and Rural Development: Ha Noi, Vietnam, 2009 ; p. 26.

31. Deaton, A.; Muellbauer, J. Economics and Consumer Behavior; Cambridge University Press: Cambridge, UK; New York, NY, USA, 1980; ISBN 978-0-521-22850-3.

32. Singh, I.; Squire, L.; Strauss, J.; World Bank (Eds.) Agricultural Household Models: Extensions, Applications, and Policy; A World Bank research publication; Johns Hopkins University Press: Baltimore, MD, USA, 1986; ISBN 978-0-8018-3149-2.

33. Meeske, W.M. Rural-Urban Migration, Food Consumption Patterns and Trends in the Local Food System: A Case Study for Vietnam. Master's Thesis, Wageningen University, Wageningen, The Netherlands, 2018.

34. Figuié, M.; Anh, D. The Food Consumption in Vietnam: Food Markets, Food Habits, Diversity and Trends; MALICA, CIRAD: Montpellier, France, 2004.

35. Ehlert, J. Emerging consumerism and eating out in Ho Chi Minh City, Vietnam: The social embeddedness of food sharing. In Food Consumption in the City: Practices and Patterns in Urban Asia and the Pacific; Routledge: Abingdon, UK, 2016; ISBN 978-1-315-65159-0.

36. Anh, D.T.; Sautier, D. Local Food Systems in Vietnam: Strengths and Opportunities; Extension Bulletin-ASPAC; Food and Fertilizer Technology Center for the Asian and Pacific Region: Taipei, Taiwan, 2011.

37. CGFR. Factsheet 3: What foods Dominate Monthly Food Expenditures? In The Vietnam Urban Food Consumption and Expenditure Study; Centre for Global Food and Resources, University of Adelaide: Adelaide, Australia, 2018.

38. World Bank. Vietnam —Food Safety and Agricultural Health Action Plan; The World Bank: Hanoi, Vietnam, 2006 ; p. 1.

39. Hoai, P.M.; Sebesvari, Z.; Minh, T.B.; Viet, P.H.; Renaud, F.G. Pesticide pollution in agricultural areas of Northern Vietnam: Case study in Hoang Liet and Minh Dai communes. Environ. Pollut. 2011, 159, 3344-3350. [CrossRef] [PubMed]

40. WHO. Vietnam Water and Sanitation: Sector Assessment Report; World Health Organization: Geneva, Switzerland, 2012.

41. ADB. Viet Nam: Urban Services and Water Supply and Sanitation Sector; Asian Development Bank: Mandaluyong, Metro Manila, Philippines, 2009.

42. Kearney, J. Food consumption trends and drivers. Philos. Trans. R. Soc. B Biol. Sci. 2010, 365, 2793-2807. [CrossRef] [PubMed]

43. Van Bui, T.; Blizzard, C.L.; Luong, K.N.; Van Truong, N.L.; Tran, B.Q.; Otahal, P.; Srikanth, V.; Nelson, M.R.; Au, T.B.; Ha, S.T.; et al. Fruit and vegetable consumption in Vietnam, and the use of a 'standard serving'size to measure intake. Br. J. Nutr. 2016, 116, 149-157. [CrossRef]

44. Kanungsukkasem, U.; Ng, N.; Van Minh, H.; Razzaque, A.; Ashraf, A.; Juvekar, S.; Ahmed, S.M.; Bich, T.H. Fruit and vegetable consumption in rural adults population in INDEPTH HDSS sites in Asia. Glob. Health Action 2009, 2, 1988. [CrossRef]

45. Nguyen, V.P.; Mergenthaler, M. Meat Consumption Patterns in Vietnam: Effects of Household Characteristics on Pork and Poultry Consumption. In Proceedings of the 53rd Annual Conference, Berlin, Germany, 25-27 September 2013. [CrossRef]

46. Dey, M.M.; Rab, M.A.; Paraguas, F.J.; Piumsombun, S.; Bhatta, R.; Alam, M.F.; Ahmed, M. Fish consumption and food securtiy: A disaggregated analysis by types of fish and classes of consumers in selected Asian Countries. Aquac. Econ. Manag. 2005, 9 , 89-111. [CrossRef]

47. Phuong, N.V.; Cuong, T.H.; Mergenthaler, M. Effects of Socio-economic and Demographic Variables on Meat Consumption in Vietnam. Asian J. Agric. Rural Dev. 2014, 4, 7-22. [CrossRef] 
48. Trung, T.Q.; Giam, D.Q.; Hai, V.T.; Thao, L.P.; Hang, N.T.T.; Son, L.T.K.; Linh, B.T.M. Factors Influencing Milk Consumption of Rural Households in Northern Vietnam. Greener J. Bus. Manag. Stud. 2014, 4, 31-40. [CrossRef]

49. Lachat, C.; Khanh, L.N.B.; Huynh, T.T.T.; Verstraeten, R.; Nago, E.; Roberfroid, D.; Kolsteren, P. Factors associated with eating out of home in Vietnamese adolescents. Appetite 2011, 57, 649-655. [CrossRef] [PubMed] 